\title{
OUTCOME OF ADOPTIONS: HAVE COUPLES REALISED THEIR DREAM?
}

\section{Wilfred van Delft, Trudie van Delft}

\section{INTRODUCTION}

Despite the wide use and success rate of ART (assisted reproductive technology) such as in vitro fertilisation, artificial insemination with donor seed, gamete donation, embryo transfer and surrogate motherhood, these technologies are not an option for many couples (for technical/biological/financial reasons and ethical/moral objections). As Grinion (2007:134) states: "The irony is that, on the one hand, reproductive technologies offer hope where previously none existed, while on the other hand they introduce a series of complex, expensive, and often morally troubling treatment modalities." After having contemplated all alternatives from either a moral, ethical, economic or all-encompassing point of view, adoption is often the only remaining alternative to couples who want a child and live the dream of being a family.

South Africa has a long practice and well-researched history of adoption (De Bruyn, 1976; De Bruyn, 1989; De Vos, 1995; Lombard, 1976; Mouton, 1976; Pakati, 1984; Van Delft, 1983).

Whereas adoptions were often undertaken somewhat haphazardly, albeit with good intentions, by social workers, lawyers, nurses and the clergy for a long time, since 1981 in terms of the Social Service Professions Act 110 of 1978 adoption has been mandated as a social workspecific professional specialisation activity. This entails that all adoptions be facilitated by a social worker either employed by a registered and accredited welfare organisation, or in private practice. Social workers in private practice wishing to do adoptions must be registered as adoption specialists with the South African Association of Social Workers in Private Practice (SAASWIPP). All social workers and welfare organisations that do not abide by the rules and regulations governing adoption practice can be accused of unprofessional conduct, and if necessary be prosecuted by the South African Council for Social Service Professions (SACSSP) in terms of the Social Service Professions Act. All practising social workers, irrespective of their field of practice, must register with the SACSSP in terms of this Act.

\section{PROBLEM STATEMENT}

Today a couple's wish to have a child of their own, experience parenthood and family life is subject to mandatory social work intervention. Social workers specialising in adoption are compelled to critically appraise the outcome of the adoptions they facilitate by means of research as pioneered by the seminal work of Jaffe and Fanshel (1970).

As stated by De Vos, Strydom and Delport (2002:383-384) and Babbie and Mouton (2005:339342), evaluative research is crucial for guiding professional practice. This article seeks answers to whether social work-facilitated adoption has been instrumental in realising the needs and dreams of the adoptive couples.

\section{RESEARCH OBJECTIVE}

The research objective is to find out how couples who chose to adopt experience parenthood and family life. Underpinning this focus is the question of whether the couples believe they made the right choice in choosing adoption and engaging with a particular welfare organisation to realise their need for a child. 


\section{RESEARCH DESIGN}

A qualitative research design is used to do descriptive research.

\section{RESEARCH METHOD}

The couples in this research all applied to adopt through Die Ondersteuningsraad (a registered welfare organisation run by the Nederduitsch Hervormde Kerk), and were screened and prepared for adoption by the specialist adoption social worker, and co-author of this article, in line with a clearly spelled out adoption process and the procedure guidelines of Die Ondersteuningsraad.

\section{Sampling}

Availability sampling was used. The entire caseload (population) of couples for the 14-year period (1989-2003) who adopted a child through Die Ondersteuningsraad was 67 couples. This period was focused on because of the continuity of social work services provided by a particular social worker dealing with all the adoptions for this period. These 67 couples adopted a total of 79 babies ( 36 boys and 43 girls). Of the total of 79 babies, 11 were placed as second adopted children, and one as a third adopted child.

During 2005 the social worker responsible for the adoptions during the abovementioned period made discreet enquiries into the whereabouts of the adoptive parents. The detailed file information was used to start the search process. Of the 67 couples, 45 (67\%) could be traced. A telephonic interview by the social worker was conducted with either the father or the mother, asking the couple to participate in the research. All couples agreed to this request and they were sent a questionnaire by registered mail and an addressed return envelope. A covering letter explaining the purpose of the research and emphasising the confidential nature of the research was attached.

Of the 45 couples who undertook to participate in the research, a total of $35(78 \%)$ completed the questionnaire. These 35 couples have a total of 47 children, of whom 11 are second adopted children and one is a third adopted child.

The 10 couples who did not complete the questionnaires were again contacted by the social worker. Although they repeatedly promised to complete the questionnaires, they did not do so. The reasons for their non-participation are unknown.

The sample represents $52 \%$ of the population of couples and $59 \%$ of the population of children. The data obtained from the questionnaires were processed in 2006.

\section{SAMPLE CHARACTERISTICS}

Some sample characteristics of the adopted children and the adoptive couples are given so as to get a better picture of the representivity of the sample in comparison with the population. All adoptive parents and adopted children are white and Afrikaans-speaking, and at the time of placement all parents were active members of the Nederduitsch Hervormde Kerk.

\section{Children}

All children, except for two who were placed three months after birth, were placed with the adoptive parents in the first month after birth. This applies to the population and the sample.

Table 1 presents the distribution of the population $(\mathrm{N}=79)$ and sample $(\mathrm{n}=47)$ of adopted children at the time of research (2005). 
TABLE 1

AGE DISTRIBUTION OF CHILDREN

\begin{tabular}{|c|c|c|c|c|c|c|}
\hline \multirow{2}{*}{$\begin{array}{l}\text { AGE IN } \\
\text { YEARS }\end{array}$} & Boys & \multicolumn{2}{|c|}{ Girls } & \multicolumn{3}{|c|}{ Total } \\
\hline & $\mathbf{N} \mathbf{n}$ & & n & $\mathbf{N}$ & $\mathbf{n}$ & $\% \mathrm{~N}$ \\
\hline $15-17$ & 4 & 12 & 12 & 16 & 16 & 100 \\
\hline $12-14$ & 16 & 16 & 7 & 32 & 14 & 44 \\
\hline $9-11$ & 7 & 11 & 6 & 18 & 10 & 56 \\
\hline $6-8$ & 5 & 3 & 3 & 8 & 5 & 63 \\
\hline $3-5$ & 4 & 1 & 1 & 5 & 2 & 40 \\
\hline Total & $\begin{array}{ll}36 & 1 \\
(50 \%)\end{array}$ & $\begin{array}{l}43 \\
667 \%\end{array}$ & & 79 & $\begin{array}{c}47 \\
(59 \%)\end{array}$ & \\
\hline
\end{tabular}

The sample (n) represents 59\% of the population $(\mathrm{N})$. The sample of boys represents $50 \%$ of the population of boys; and the sample of girls represents $67 \%$ of the population of girls. As can be seen from the age distribution, the sample compares very favourably with the population.

\section{ADOPTIVE COUPLES}

Table 2 presents the distribution of the population $(\mathrm{N}=67)$ and sample $(\mathrm{n}=35)$ of adoptive couples at the time of adoption of first and second and third children. The percentage of sample representation of the population is given in brackets in the bottom row.

TABLE 2

\section{AGE DISTRIBUTION OF ADOPTIVE COUPLES}

\begin{tabular}{|c|c|c|c|c|c|c|}
\hline \multirow[t]{2}{*}{ AGE } & \multicolumn{2}{|c|}{$1^{\text {st }}$ child } & \multicolumn{2}{|c|}{$2^{\text {nd }}$ child } & \multicolumn{2}{|c|}{$3^{\text {rd }}$ child } \\
\hline & $\begin{array}{c}\text { Husband } \\
\mathbf{N} \text { n }\end{array}$ & $\begin{array}{l}\text { Wife } \\
\text { N n }\end{array}$ & $\begin{array}{c}\text { Husban } \\
\quad \mathbf{n}\end{array}$ & $\begin{array}{l}\text { Wife } \\
\text { N n }\end{array}$ & $\begin{array}{c}\text { Husband } \\
\mathbf{N} \text { n }\end{array}$ & $\begin{array}{l}\text { Wife } \\
\mathbf{N} \text { n }\end{array}$ \\
\hline $46-49$ & & & 1 & & & \\
\hline $42-45$ & 52 & & 2 & & & \\
\hline $38-41$ & 128 & 7 & 3 & 4 & 1 & \\
\hline $34-37$ & $24 \quad 12$ & 2413 & 2 & 1 & & 1 \\
\hline $30-33$ & $24 \quad 11$ & 2912 & 3 & 6 & & \\
\hline $26-29$ & 22 & 7 & & & & \\
\hline Total & $\begin{array}{l}6735 \\
(52 \%)\end{array}$ & $\begin{array}{c}6735 \\
(52 \%)\end{array}$ & 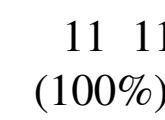 & $\begin{array}{c}1111 \\
(100 \%)\end{array}$ & $\begin{array}{cc}1 & 1 \\
(100 \%)\end{array}$ & $\begin{array}{cc}1 & 1 \\
(100 \%)\end{array}$ \\
\hline
\end{tabular}


Couples represent $52 \%$ of first child adoptive couples, $100 \%$ of second child adoptive couples, and $100 \%$ of third child adoptive couples of the population $(\mathrm{N})$. These percentages can be regarded as good representations of the population. The fact that relatively few couples adopted a second child and even fewer a third child, even though all couples would have preferred to have at least two children, reflects the relative scarcity of babies available for adoption.

\section{Marital status of adoptive couples at the time of research $(n=35)$}

Thirty two $(91 \%)$ couples remained married to the same spouse with whom they had adopted. One (3\%) couple got divorced and neither partner was remarried at the time of research. Two (6\%) couples experienced the loss of their partner (husbands) to death, of which one $(3 \%)$ mother remarried.

\section{Occupations of adoptive mothers at the time of research $(n=35)$}

Of the 35 adoptive mothers only seven (20\%) were full-time housewives, the others being employed full-time/part-time in rank order as secretaries/admin staff (11), in their own business (3), managers (3), teachers (2), receptionists/dental assistants (3), artists (2), ballet teachers (1), academics (1), bookkeepers (1) and dressmakers (1).

\section{Occupations of adoptive fathers at the time of research $(n=34 *)$}

(* One father was deceased at the time of research.)

All fathers were employed at the time of research, although one father had lost his job and had to start a business from scratch. Ranked in order of prevalence, fathers worked as managers (5), in their own business (5), financial planners (4), technical managers (4), engineers (3), farmers (3), administrative workers (3), artisans (2), salesmen (2), journalists (1), attorneys (1) and dentists (1).

\section{Research instrument}

Taking into account the dynamics of a number of critical events in the life cycle of a young family (Carter \& McGoldrick, 1989), as well as by the findings by Smith and Logan (2003), Howe (1996) and De Bruyn (1976), the researchers constructed a questionnaire consisting of close-ended and open-ended questions with the purpose of obtaining qualitative data concerning the couples' experiences of parenthood and being a family by means of adoption.

\section{ADOPTION AS AN OPTION TO FORM A FAMILY}

According to Nijs (1972:1542), couples' longing for a child is an existential reality that does not lend itself to being reduced to the dimensions of a psychological problem. (Translated from the Dutch: De vraag waarom een paar een kind verlangt is een existentiële werkelijkheid, die zich niet laat reduceren tot de afmeting van een psychologisch probleem.)

A constructivist approach to the study of adoption would entail adoption being viewed as a process over time without a definite beginning and end. It would therefore not ask whether adoption is successful or not, but rather how the choice to construct a family by means of adoption is experienced by, for instance, the parents. These experiences are, of course, linked to a variety of factors of which the time at which the question is asked is important. Parents may experience their functioning as a family quite differently at various stages of the family life cycle, as so well discussed by Carter and McGoldrick (1989). The time of research therefore represents a "punctuation", so to speak, in the ongoing process, and reflects perceptions and experiences of persons at that specific time or punctuation. 
The researchers are of the opinion that a couple who adopt a child are not doing so in the first instance to test whether they can be successful adoptive parents. They adopt to fulfil the need for parenthood, experience family life and become part of the bigger parenting fraternity. The process of realising this need ideally starts with a couple exploring each other's willingness and readiness to start a family and coming to a mutually satisfactory decision as to the timing of this critical life event (Berger, McBreen \& Rifkin, 1996:133).

Whether this need is ideally fulfilled by having their own biological children or deciding to adopt, the striving is towards the same end result, namely the realisation of parenthood and family life. This is in essence the same for many couples irrespective of whether they adopt or have their own biological children.

Adoption as such is therefore placed alongside a variety of forms of family formation and functioning without wanting to suggest that adoption is in any way a potentially pathological social construct that needs constant monitoring to determine whether adoption is in fact the right "cure" for childlessness.

Parenting and forming a family start at the moment a couple have a baby of their own and this really carries on throughout life (Carter \& McGoldrick, 1989).

Yet the fact remains that satisfying the need for parenting and a family is much more controlled and influenced by external events and interventions in the case of childless couples who wish to adopt than it is for couples having their own biological children. This reality of external factors entailing, inter alia, professional intervention and involvement with a number of role players involved in adoption places adoption in the arena of special concern, just as is the case in researching a number of other issues in family life such as divorce, reconstituted families, single-parent families and successful families.

\section{RESEARCH FINDINGS}

\section{Couples' initial experiences of the adoption process}

In addition to the overall positive statement made about the adoptive process, eight (23\%) couples specified that they experienced a lot of emotional support from the adoption section, six (17\%) couples found the adoption section very sympathetic, and three (9\%) couples specifically mentioned the interest the adoption section had in their welfare. Three (9\%) couples highlighted the professional service they received.

Some said that, although the screening process procedures were somewhat irritating at the beginning, on reflection it was in fact a growth experience. Stressors specifically identified were: a very painful and emotionally draining experience to start the screening process; the unavoidable stress that accompanies the long waiting period after being accepted as prospective adoptive parents; too much repetition of questions and issues around infertility, marital relationships and adoption per se; feelings of aggression towards the social worker and Die Ondersteuningsraad for not being accepted as adoptive parents simply on the grounds of testimonials from people such as church pastors and other referees.

\section{Formation of a family as envisaged by couples}

The answers fall into three clusters. In cluster one $32(91 \%)$ couples reported that family formation went quite as smoothly as they had envisaged. They immediately formed a bond with the newborn baby and quickly experienced being a family. In cluster two two couples (6\%) 
reported that family formation was hampered in the beginning because of the baby's illness. The couple had to make many lifestyle changes and the grandparents assisted them very well. Eventually the problems were overcome and family formation proceeded very well. In cluster three one $(3 \%)$ couple reported that family formation was quite stressful because of behaviour and health problems of the baby. The couple struggled for a long time to stabilise the child's health and behaviour, and even at the time of the research the family struggled to experience the harmonious and rewarding family life they had envisaged.

The issues that positively impacted on the formation of a family were, inter alia, that family and friends shared their joy of having a baby; the couple saw no difference between themselves and parents who had their own biological children; they felt like a normal couple with a child; they freely shared their experiences with other parents; and the challenges to adapt to a new life routine and budgeting were meaningful, even if they were demanding at times.

\section{Experience of motherliness and fatherliness as envisaged by couples}

Motherliness was envisaged by 33 (94\%) mothers very soon after the baby was placed. One (3\%) mother said that she did not experience motherliness soon after receiving the baby and that she had to consciously work on letting herself experience her new role. Even at the time of the research she did not experience motherliness in the way she was hoping to experience it. Two $(6 \%)$ mothers stated that they initially had a difficult time experiencing the feelings of motherliness they had expected to experience. It was difficult in the beginning, but as time moved on and the babies started to respond to them more and more, they developed very satisfactory feelings of motherliness.

Thirty four (97\%) of the fathers experienced fatherliness as envisaged immediately after the baby was placed with them. (The wife of the father who was deceased at the time of the research answered on his behalf.) Only one (3\%) father stated that it took some time to experience feelings of fatherliness, but when the baby started to respond to him positively and affectionately, the feelings of fatherliness quickly developed.

Statements reflecting the experience of motherliness and fatherliness include: we never think of the child other than he or she being our own child; to be my son's father is a privilege; being a father or mother is very nice, but it is hard work to always remain the loving parent, yet rewarding in the end; being a mother makes me feel whole and fulfilled.

\section{Family's and friends' awareness of and attitudes towards couples' intention to adopt}

Table 3 indicates whether adoptive couples shared their intention to adopt with their parents, close friends and significant others. This information is important in relation to the later acceptance of the adoptive child by family and friends. It is of course equally relevant for the adoptive parents themselves when their decision to adopt is supported by significant people in their lives. 
TABLE 3

AWARENESS AND ATTITUDES OF SIGNIFICANT OTHERS IN RELATION TO ADOPTION

\begin{tabular}{|l|c|c|c|c|c|}
\hline \multirow{2}{*}{ SIGNIFICANT OTHERS } & \multicolumn{2}{|c|}{ Awareness } & \multicolumn{3}{c|}{ Attitude } \\
\cline { 2 - 7 } & Yes & No & Positive & Negative & Unsure \\
\hline Parents on both sides & 34 & 1 & 32 & 1 & 1 \\
\hline Family & 34 & 1 & 31 & 1 & 2 \\
\hline Friends & 32 & 3 & 29 & 2 & 1 \\
\hline Minister of religion & 35 & 0 & 35 & & \\
\hline General practitioner & 1 & & 1 & & \\
\hline Colleagues at work & 15 & & 14 & 1 & \\
\hline
\end{tabular}

Of all the couples who shared their intentions with their parents, only one couple encountered a negative attitude from the husband's parents, and one couple was not sure what the wife's parents really felt. Thirty four couples shared their intention to adopt with friends and 31 couples received positive feedback; one couple received negative feedback and two couples were not sure of how their family really felt.

All but three couples' friends knew that the couple wanted to adopt a baby and 29 couples received positive feedback from friends; two couples received negative feedback and one couple was unsure of exactly how their friends felt about adoption.

The negative attitudes that the few couples encountered all revolved around the themes of "you don't know what you are getting" and "blood ties are very important". The couples encountering an unsure attitude stated that the family and friends never stated clearly where they stood in relation to adoption.

The overall positive attitude towards adoption by significant others from the start of the adoption process was experienced as a great support during the stressful screening process and waiting period for a child after approval as adoptive parents.

\section{Contact with other adoptive couples}

Six $(17 \%)$ couples stated that they had a need to have such contact so as to exchange ideas and information regarding adoption matters and as a future resource. Twenty nine (82\%) couples stated that they had no need or desire to deliberately seek out other adoptive couples, although $20(57 \%)$ of these couples had sporadic contact with other adoptive couples, but this was nonintentional.

Couples clearly stated that as a family they wanted to function without constantly having to be reminded of the "adoptive status". If someday they experienced the need to make such contact, they would do so via a social worker who knew other adoptive couples. 


\section{Presence of grandparents}

Grandparents can play a major role in the functioning of a family with young children, as pointed out by Carter and McGoldrick (1989:243-244). Thirty (86\%) adoptive families have at least one grandfather or one grandmother. The families who have grandparents are indeed fortunate, as by far the majority of the couples reported that grandparents play a significant role in the lives of the family and especially of their grandchildren. Except for two families, all grandparents clearly accepted their grandchild, reached out to the grandchild, and the grandchild identified positively with the grandparents and demonstrated reciprocal affection and concern. The two couples who reported negatively on the role that grandparents play stated that the grandparents did not live nearby and that there was relatively little direct contact with them. The grandparents did, however, acknowledge their grandchild.

\section{Interaction with the wider community of parents}

On the issue of whether couples feel that they are part and parcel of the community of parents in the social context such as school, church and other socio-cultural structures, $30(86 \%)$ stated that they felt very comfortable in their roles as parents in the community. Two (6\%) stated that they felt a bit uneasy at the beginning, because they were much older than most parents and their child was much younger than the other children. They were very aware of the fact that they were being observed by the more experienced parents. However, in time this feeling of self-consciousness disappeared and they quickly became more self-assured in their role as parents. Not a single couple reported that they were at any time confronted in any negative way by other parents about the fact that their child was adopted. In fact the matter of adoption was scarcely mentioned and they were accepted as a family like most other families. This bonded them as a family.

\section{Family functioning and satisfaction}

Sixteen (46\%) couples stated that they view their family's functioning as mutually satisfactory and their family life as similar to that of most of their family and friends. Eighteen (51\%) couples are of the opinion that their daily family functioning is better than that of their family and friends. According to these couples, they are functioning better because they are much more aware of the great privilege of having been given the opportunity to adopt a child. They also stated that as couples they spoke much more about feelings and experiences of being a family than did many of their family and friends.

Only one $(3 \%)$ couple stated that they were not a happily functioning family because of the health and behavioural problems of their child. Couples also commented on the high incidence of divorce among family and friends, and that this fact makes them acutely aware that they must try harder to ensure a happy and well-functioning family. The fact that they went through quite a stressful period during infertility treatment and screening for adoption taught the couples to be very honest with each other and to share emotions and experiences before serious problems developed. The couples observed that when you have tried much harder than most couples to have a family, you also work harder to protect the family and one another.

\section{Awareness of being an adopted child}

The question as to whether a child knows that he/she is adopted is an obvious one when researching family functioning. The question would be how the child responds to the reality of adoption. In the sample $31(88 \%)$ couples reported that their children knew they were adopted. Three $(5 \%)$ couples reported that their children did not yet know about their adoption, and one (3\%) couple decided not to tell the child. The couples whose children were aware that they had 
been adopted stated that the children accepted the fact quite well, and although they sometimes spoke about the adoption, it seemed not to bother them yet. One couple stated that their child did not accept the fact easily and often discussed why he was adopted and why his mother could not look after him. This child is not overtly dissatisfied with the adoption, but it is a factor that often plays on his mind. The parents responded to their child's questions as well as they could. The one couple that decided not to tell their child stated that their child was extremely sensitive and that this knowledge would upset him far too much. The couple was not prepared to deal with the trauma they foresaw in telling their child.

The children of couples who knew about their adoption were informed about this in early childhood (2-6 years of age). Couples who have more than one child stated that in one case the one child accepted the fact without any desire for detail and explanation, whereas the other child wanted to talk about it far more and in more detail.

It seems that the children in the early stages of adolescence did not raise the issue of adoption, as one would expect as part of the search for identity in the Eriksonian "identity versus role confusion" ego crisis (Erikson, 1976), and also as discussed by Lourens (2002).

The fact that the majority of children know about their adoption and are well accepted in the family and friendship circles may place less focus on adoption as a focus area in searching for personal identity. Couples who reported some initial stress with the adoption reality experienced by their child consulted counsellors who used play therapy as a means to resolve the conflict successfully. Although couples stated that they did not think that the knowledge of the adoption was harmful to their children, they also acknowledged that the adoption might become an issue as the children grew older. The parents reported that they were prepared to continue discussing this with an open mind and to consult with an adoption social worker or psychologist. One (3\%) couple stated that they were not absolutely sure about how their child experienced his adoption "deep inside" as he was a rather introverted child.

\section{Contact with the child's biological parent/family and future contact}

Fourty (85\%) children out of the sample of 47 placed were so-called "undisclosed adoptions", meaning that the biological mother and the adoptive parents did not know each other's names and addresses.

An undisclosed adoption, however, does not entail total anonymity. The social worker, in consultation with the adoptive couple and biological mother, may use her discretion as to the degree of anonymity that will be maintained. In the case of the aforementioned 40 children, 24 $(60 \%)$ children were placed according to the decision made by the social worker and the adoption panel of Die Ondersteuningsraad. Sixteen (40\%) children were placed with parents selected by the biological mothers from written profiles of adoptive parents presented to the mothers by the social worker. Of these 16 children, five (31\%) children's biological mothers and adoptive parents engaged in sporadic letter writing via the social worker, and shared information on the progress of the child and the comings and goings of the biological mothers. This correspondence gradually terminated spontaneously as the biological mothers realigned their own personal lives. The biological mothers do, however, inform the social worker of their whereabouts by phoning or writing letters to them. All these communications are documented in the adoption file. 
Three (19\%) of the 16 children's biological mothers and adoptive parents met each other in person once during the placement process. Thereafter continuous contact was maintained by exchange of letters and photos sent via the social worker.

Seven $(15 \%)$ out of the sample of 47 children were placed as "disclosed adoptions", which means that the biological mother requested that her baby be placed with a specific couple known to her. Continuation of contact between the biological mother and the adoptive family was therefore a matter of personal choice.

The issue of whether a child would want to make future personal contact with a biological parent is a reality most adoptive parents think and speak about in the family (Andrews, Hill, Lawder, Lowder \& Sherman, 1969; Barth, 2002; Brodzinsky \& Palacios, 2005). In the sample three $(6 \%)$ children indicated to their parents that they would someday like to meet their biological mothers. Eleven $(23 \%)$ children had already stated that they had no need to meet a biological parent and their parents agreed to this and saw no reason for such contact. Seventeen (48\%) couples had indicated that they would make personal contact with the biological parent (mother in most cases) via the social worker and in accordance with the Child Care Act, should such a need arise.

All the couples who had some or other contact with the biological mother via the social worker in the form of letter writing clearly stated that they did not experience any problems maintaining the contact and that they also did not see any negative reactions in their children when the issue of the biological mother arose in discussions.

The couples who had a disclosed adoption reported that they experienced no problems of any kind because the biological mothers knew the adoptive parents and the parties had little contact.

It is, however, clear that couples are divided on the issue of future contact with a biological parent. At the age of 18 an adopted child, with the permission of the adoptive parent(s), may make contact with the biological mother, and at the age of 21 no restrictions are placed on the adoptee with reference to making contact with the biological parent. This contact may either be initiated by the biological mother or the child. In all cases, a social worker must be the intermediary.

\section{Psychosocial functioning of the children}

The views of parents regarding the psychosocial functioning focused on emotional, social, moral and scholastic functioning. Some parents could not answer all the questions as the child was still very young. The responses of parents about their children are presented in Tables 4, 5 and 6. 
TABLE 4

EMOTIONAL FUNCTIONING OF CHILDREN (N=47)

\begin{tabular}{|l|c|c|}
\hline \multicolumn{1}{|c|}{ DIMENSION } & n & \% \\
\hline$\bullet \quad$ Identifies with male/female role as observed in behaviour & 39 & 83 \\
\hline$\bullet \quad$ Involves parents in personal matters & 37 & 79 \\
\hline$\bullet \quad$ Experiences emotional security & 32 & 68 \\
\hline$\bullet \quad$ Mood is acceptable to parents & 35 & 74 \\
\hline$\bullet \quad$ Healthy self-image for his/her age & 36 & 77 \\
\hline$\bullet \quad$ Sleeps over with friends & 36 & 77 \\
\hline
\end{tabular}

Issues that parents mentioned as things they needed to attend to in their child included: child is too attached to the parent; personal levels of security are threatened; anxiety levels increase dramatically when things don't work out as planned; mild depression; easily becomes emotionally rebellious; child has a "very soft heart"; and self-image is easily hurt. By far the majority of children appeared to demonstrate stable emotional functioning as reported by their parents.

TABLE 5

SOCIAL FUNCTIONING OF CHILDREN (N=47)

\begin{tabular}{|l|c|c|}
\hline \multicolumn{1}{|c|}{ DIMENSION } & n & $\%$ \\
\hline - Gets along well with siblings and other children & 39 & 83 \\
\hline - Makes/has friends & 37 & 79 \\
\hline - Takes part in social/cultural activities & 38 & 81 \\
\hline - Not unduly anxious in new situations & 33 & 70 \\
\hline
\end{tabular}

Parents mentioned the following issues that needed to be attended to: child has a domineering interpersonal style; demonstrates aggression towards people; does not make friends easily; loses courage and motivation when things don't turn out as planned; does not participate in school activities and must be encouraged; has high levels of anxiety if things are "out of balance"; and is not always sure of himself/herself.

These concerns are shared by many parents across the population and they need to deal with them. In general, however, parents seem to think that socially their children function quite well. 
TABLE 6

MORAL FUNCTIONING OF CHILDREN (N=47)

\begin{tabular}{|l|c|c|}
\hline \multicolumn{1}{|c|}{ DIMENSION } & $\mathbf{n}$ & $\mathbf{\%}$ \\
\hline - Identifies with parents' values and moral code & 34 & 72 \\
\hline - Acceptable levels of empathy with others & 32 & 68 \\
\hline - Very attached to a pet & 34 & 69 \\
\hline
\end{tabular}

Parents commented as follows on the moral functioning of their children: child is far too sympathetic towards others to his own detriment; too much aggression shown towards others; and child gets extremely upset when seeing a child with a disability. In general, parents feel that morally their children are functioning quite well. Parents who express some concerns are optimistic that they will be able to deal with the problems and that they will consult with professionals when needed.

TABLE 7

SCHOLASTIC FUNCTIONING OF CHILDREN (N=45)

\begin{tabular}{|l|c|c|}
\hline \multicolumn{1}{|c|}{ SCHOLASTIC FUNCTIONING } & $\mathbf{n}$ & $\%$ \\
\hline$\bullet$ Below average & 1 & 2 \\
\hline$\bullet$ Average & 17 & 36 \\
\hline$\bullet$ Above average & 16 & 34 \\
\hline$\bullet \quad$ Unknown & 13 & 28 \\
\hline
\end{tabular}

$22 \mathrm{n}=45$ as there are two pre-school children. See Table 1.

It is not known why 13 children's parents chose not to complete this section. The child who is scholastically below average is attending a special school and progresses satisfactorily.

\section{Learning, emotional and behavioural problems of children}

Twenty two $(47 \%)$ of the children are reported to have experienced some or other learning, emotional or behavioural problems for which professional advice and intervention were sought. Table 8 provides the details. 
TABLE 8

PROBLEMS EXPERIENCED BY CHILDREN

\begin{tabular}{|c|c|c|c|c|c|c|c|}
\hline & & & & \multicolumn{2}{|c|}{$\begin{array}{l}\text { Positive } \\
\text { n } \%\end{array}$} & \multicolumn{2}{|c|}{$\begin{array}{c}\text { Slow progress } \\
\text { n }\end{array}$} \\
\hline 1 Attention deficit disorder & 7 & 15 & Occupational therapy & 6 & 86 & 1 & 14 \\
\hline 2 Reading and writing & 5 & 11 & $\begin{array}{l}\text { Remedial teaching }+ \\
\text { occupational therapy }\end{array}$ & 4 & 80 & 1 & 20 \\
\hline 3 Speech problem & 2 & 4 & Speech therapy & 2 & 100 & - & - \\
\hline $\begin{array}{l}4 \text { Traumatised after car } \\
\text { hijack }\end{array}$ & 2 & 4 & Psychologist & 2 & 100 & - & - \\
\hline $\begin{array}{l}5 \text { Separation anxiety when } \\
\text { going to school }\end{array}$ & 1 & 2 & $\begin{array}{l}\text { Psychologist (play } \\
\text { therapy) }\end{array}$ & 1 & 100 & - & - \\
\hline $\begin{array}{l}6 \text { Adaptation in new } \\
\text { family after parent } \\
\text { remarries/ parent } \\
\text { involved with someone }\end{array}$ & 2 & 4 & $\begin{array}{l}\text { Social worker }+ \text { play } \\
\text { therapy }\end{array}$ & 1 & 50 & 1 & 50 \\
\hline $\begin{array}{l}7 \text { Aggression towards } \\
\text { biological parent for not } \\
\text { phoning }\end{array}$ & 2 & 4 & Psychologist & 2 & 100 & - & - \\
\hline 8 Very shy to socialise & 1 & 2 & Psychologist & 1 & 100 & - & - \\
\hline
\end{tabular}

Apart from problem 7, all the problems experienced are quite common amongst children. However, the rather high prevalence of attention deficit disorder and reading and writing problems is disturbing. The international average prevalence figures for elementary school children lie between $4 \%$ and $12 \%$ depending on the assessment criteria being used (Brown, Freeman, Perrin, Stein, Aamler, Feldman, Pierce \& Wolraich, 2001:1-2).

The overall positive outcome of professional intervention, specifically for attention deficit disorder and learning problems, is indeed very encouraging as is the willingness of parents to involve professionals.

\section{Achievements and career interests of children}

Some parents indicated that their children had achieved very well in the following areas: 
TABLE 9

ACHIEVEMENTS (N=47)

\begin{tabular}{|ll|c|c|}
\hline \multicolumn{2}{|c|}{ CATEGORY OF ACHIEVEMENT } & n & \% \\
\hline 1 & Musically gifted & 6 & 13 \\
\hline 2 & Very active in, and good at, sports & 22 & 47 \\
\hline 3 & Drama, singing & 12 & 25 \\
\hline 4 & Dancing & 10 & 23 \\
\hline 5 & Academic top achievers & 8 & 17 \\
\hline 6 & Leadership qualities & 3 & 6 \\
\hline 7 & Language ability, poetry and writing & 3 & 6 \\
\hline 8 & Debating & 4 & 8 \\
\hline 9 & Visual art, drawing and painting & 6 & 13 \\
\hline 10 & Exceptional technical and mechanical skills & 3 & 6 \\
\hline
\end{tabular}

On the issue of whether children had already expressed any interest in a future career, 25 parents reported as follows on $11(61 \%)$ of the 18 boys and $19(66 \%)$ of the 29 girls: quantity surveyor; therapeutic profession to help people; technical/mechanical field; working with children; master artisan; pilot; engineer; farmer; professional sportsman; economist; game ranger; restaurant owner; actor and singer; interior decorator; architect; advocate; microbiologist; public relations official; accountant; speech therapist; psychologist; teacher; hairstylist/beautician; sports coach; horse-riding teacher; and veterinary surgeon. A number of parents indicated that their child had not yet expressed any future career options.

From the data in Table 9 it is clear that the children have quite a wide and varied field of interest demonstrating that this issue is discussed at home, that thought is given to careers, and that the children see themselves in the role of working adults. The fact that there are a number of children who demonstrate exceptional abilities reflects the normal manifestation of this reality and underscores the fact that adopted children are probably as gifted as non-adoptive children.

\section{Health and physical development of the children}

Health and physical development of the children is an important factor in the overall functioning of the child and the family. Parents reported that $42(89 \%)$ of the children experienced good health. The health problems that five $(9 \%)$ children experienced are: being seriously overweight; asthma; hay fever; and sinusitis. These conditions are of such a nature that specialist medical treatment is required.

Parents reported that $44(94 \%)$ children demonstrated normal physical development. The problems of the three $(6 \%)$ children experiencing problematic physical development included: 
grows too quickly for his age; physical development by far exceeds emotional development; and is of below average height. These children were also receiving specialist medical attention.

\section{"Highs" and "lows" in family life}

Twenty five (72\%) couples indicated the "highs" and "lows" in family life whereas $10(28 \%)$ did not indicate them. Table 10 indicates what these "highs" and "lows" are.

TABLE 10

“HIGHS" AND "LOWS" IN FAMILY LIFE

\begin{tabular}{|c|c|}
\hline “HIGHS” IN FAMILY LIFE & “LOWS” IN FAMILY LIFE \\
\hline $\begin{array}{l}\text { - Being a happy and stable family } \\
\text { - Wonderful to see a child grow up under } \\
\text { your guidance and nurturing } \\
\text { - Child spontaneously draws the family } \\
\text { to being more closely linked together } \\
\text { - The exceptional academic and sports } \\
\text { achievements of children } \\
\text { - Touring Europe as a family, making a } \\
\text { - Child's spontaneous personality makes } \\
\text { us see the world in a much more } \\
\text { positive way } \\
\text { Moving to a smallholding with horses } \\
\text { and touring the USA }\end{array}$ & $\begin{array}{l}\text { - School achievements not always } \\
\text { satisfactory } \\
\text { - Child experiences a learning problem } \\
\text { which impacts on family life } \\
\text { - Death of adoptive father at age two } \\
\text { - Being badly bitten by a neighbour's } \\
\text { dog and traumatised } \\
\text { - Mother and son argue too much and } \\
\text { - Then make up again } \\
\text { - Feenage years are very stressful } \\
\text { Father has lost his job, family in } \\
\text { survival struggle but support each other } \\
\text { well Parents got divorced and mother died some } \\
\text { time later }\end{array}$ \\
\hline
\end{tabular}

The data in Table 10 indicate that family life is neither overwhelmed by problems nor is it without its disappointments and challenges. The "low" points in family life are not exceptional and in no way should one view them as being in a problematic reciprocal relationship to adoption per se.

\section{In retrospect}

The couples were asked whether they would recommend adoption and adopt again if "they had to do it all over again", so to speak.

Thirty two (91\%) couples responded that they would recommend it and do it again. Three (9\%) said that they would recommend adoption only if there were absolutely no alternatives and the couple had exhausted all other options. One of these couples said that they were not sure whether they would adopt if given the option to "do it all over again." These three couples stated that raising a child is very stressful, especially if a child has some or other problem.

The couples who felt satisfied with their decision to adopt stated the following issues that prospective adopted couples must bear in mind when contemplating adoption:

- Do not shy away from counselling about childlessness and your relationship;

- Do not wait too long before you adopt; 
- Physical matching of adoptive couple and biological parent(s) will help in the child's growing up years;

- Be open about adoption with others without dramatising it;

- Talk openly with your children about their adoption when the issue comes up or there is an appropriate moment;

- Work hard on the family relationship and bonding;

- Use the correct adoption channels and do not take short cuts. Make use of accredited social workers and organisations;

- Have the story about the adoption in your head. Don't stumble over your words and create an atmosphere of "this is a no-go area";

- Prepare yourself for parenthood and accept advice and assistance from family and friends;

- Accept the child for what he/she is and strive for maximum development of potential.

\section{Future involvement with Die Ondersteuningsraad}

Thirty two (91\%) couples reported that they would reach out to Die Ondersteuningsraad when the need arose in the future regarding adoption issues. They trusted the organisation and had experienced a professional service. However, three couples (9\%) stated that they were disappointed with the organisation as they felt that after the baby had been placed with them the social worker did not continue to follow up the placement. They felt that the organisation should keep ongoing contact with couples who adopt a child. This is, of course, not a thought shared by $91 \%$ of the couples, who preferred to initiate contact with the organisation rather than vice versa. Yet the need expressed is real, even if a minority of parents have this need.

\section{DISCUSSION OF FINDINGS}

The sample of adoptive couples and children can be regarded as a valid representation of a population of adoptive children and couples served by Die Ondersteuningsraad for the period under discussion (1989-2003).

Functioning as parents and as a family is a complex interaction between a number of factors (Carter \& McGoldrick 1989). This research attempted to address a number of these factors as they apply to adoptive families.

It is clear from the data presented that by far the majority of couples have experienced adoption very positively and foresee this experience as continuing into the future.

The majority of couples succeeded in forming a family, and experienced parenthood to the satisfaction of themselves and to the benefit of their children. The children were, with the exception of a very few, well adjusted and coped well with the challenges they encountered.

Adoptive parents experienced themselves as part of the larger community of parents and in no way experienced themselves and their children as being a "marginalised" group.

Parents and children confronted challenges common to most families. There was no overriding evidence that adoption impacted negatively on the formation of well-functioning and happy families.

The fact that all couples were professionally counselled by the social worker may contribute to the couples' very informed decision and preparedness to adopt. All couples were active members of the Nederduitsch Hervormde Kerk and were so at the time of applying for 
adoption. Their Christian values and lifestyle may be important factors in their ability to create and maintain stability in their personal lives, their marriages and the lives of their children.

Judging from the comments of parents, the majority of the children, through their presence and behaviour, seemed to make a meaningful contribution to the positive and rewarding experience of being a family.

Even though the overall functioning of most of the families is positive, there are a few children and parents who do experience a lot of stress and for whom adoption has not realised their dream. Whether or not social workers and the organisations doing adoptions should regularly enquire about the functioning of the adoptive family, and by so doing identify and deal with a variety of problems, needs much more thought (Barth \& Miller, 2000). The majority of adoptive parents in this sample would not prefer or accept such ongoing involvement. They have the knowledge and ability to consult a social worker or other professionals when the need arises, as is in fact stated by the majority of couples. However, based on the research findings of Barth and Miller (2000) and Barth (2002) concerning post-adoptive services, this issue merits much more research in the South African context.

It is a major concern that the prevalence of attention deficit disorder and learning problems is so high. Among the sample of adopted children, it is not clear whether this a matter of overdiagnosis on the part of the teacher or other professionals. Are attention deficit disorder and learning problems really on the increase? Or are adoptive parents overly concerned with the performance of their child and the over-react when a child shows some signs that also manifest in attention deficit disorder and so fear the worst? These are issues that require in-depth investigation.

\section{CONCLUSION}

The present research results confirm other research findings (Brodzinsky \& Palacios, 2005; Groze, 1996; Howe, 1996; Jafee \& Fanshel, 1970; Smith \& Logan, 2003; Wilson, 2004) that found adoption to have overall good results. These balance research findings by Doyer and Roux (2000) and Adams (2002) as well as popular belief that suggests that adoption is a potential "minefield" of problems and that adoption practice needs a drastic "rethink" in terms of, inter alia, much more contact with the biological parent(s). Through continued research on the outcomes of adoptions and well-monitored implementation of new practices and procedures, adoption can remain and continue to become a viable choice for couples and for biological parents who are contemplating having their baby placed for adoption.

As to whether the present research is a skewed presentation of adoption outcomes linked to a sample that does not present the average adoptive couple, this can only be determined once more follow-up research in the South African context is done on a larger and continuous scale. What can be concluded from this research is that given a well-qualified and experienced social worker, proper screening and an adoption preparation plan, parents who have strong religious affiliations and are well accepted by the family and peers, parents who experience a solid marriage, and parents who are open to consulting with professionals when the need arises, there is a good chance of positively experiencing the much-longed-for experience of parenthood and family life.

The fact that all the children are well cared for (and by far the majority feel safe and secure in their family despite some problems encountered) is also to the benefit of society at large. 
This fact should be a consolation to the biological mothers who so courageously decided, given their circumstances at the time, that adoption would be in the best interests of their babies. In this research the results show that the best interests of their children were indeed served.

\section{REFERENCES}

ADAMS, M. 2002. Our son, a stranger: adoption breakdown and its effects on parents. Montreal: McGill-Queen's University Press.

ANDREWS, R.G., HILL, J.G., LAWDER, E.A, LOWDER, K.D. \& SHERMAN, A.E. 1969. Follow-up study of adoptions: post-placement functioning of adoption families. Child Welfare League of America.

BABBIE, E. \& MOUTON, J. 2005. The practice of social research. Oxford: Oxford University Press.

BARTH, R.P. 2002. Outcomes of adoption and what they can tell us about designing adoption services. Adoption Quarterly, 6(1):45-60.

BARTH, R.P. \& MILLER, J.M. 2000. Building effective post-adoption services: what is the empirical foundation? Family Relations, 49(4):447-455.

BERGER, R., McBREEN, J.T. \& RIFKIN, M.J. 1996. Human behavior: a perspective for the helping profession. New York: Longman.

BRODZINSKY, D.M. \& PALACIOS, J. 2005. Psychological issues in adoption: research and practice. Praeger: Westport.

BROWN, R.T., FREEMAN, W.S., PERRIN, J.M., STEIN, M.T., AAMLER, R.W., FELDMAN, H.M., PIERCE, K. \& WOLRAICH, M.L. 2001. Prevalence and assessment of attention deficit disorder/hyperactivity disorder in primary care settings. Pediatrics, 107(3):1-2. CARTER, B. \& McGOLDRICK, M. 1989. The changing family life cycle. Boston: Allyn and Bacon.

DE BRUYN, M. 1976. Die aannemingsproses met spesiale aandag aan die aannemende ouers. Pretoria: University of South Africa. (Unpublished DPhil Thesis)

DE BRUYN, M. 1989. Privaataannemings. Social Work, 25(4):262-270.

DE VOS, L. 1995. 'n Opvolgstudie van kinders met spesiale behoeftes wat later aangeneem is. Pretoria: University of South Africa. (Unpublished MA Dissertation)

DE VOS, A.S., STRYDOM, H. \& DELPORT, C.S.L. 2002. Research at grass roots: for the social sciences and human service professions. Pretoria: Van Schaik.

DOYER, A.W. \& ROUX, J.P. 2000. Die selfverstaan van die aanneemgesin. The Social Work Practitioner-Researcher, 112(3):184-194.

ERIKSON, E.H. 1976. Adulthood. New York: Norton.

GRINION, P.E. 2007. A phenomenological study into infertility and assisted reproductive technologies: USA and Jamaica compared. Durban: University of KwaZulu-Natal. (Unpublished DPhil Thesis)

GROZE, V.K. 1996. Successful adoptive families: a longitudinal study of special needs adoptions. Westport: Praeger. 
HOWE, D. 1996. Adopters and adoption: reflections on parenthood and children. London: British Agencies for Adoption and Fostering.

JAFFE, B. \& FANSHEL, D. 1970. How they fared in adoption: a follow-up study. New York: Columbia University Press.

LOMBARD, S.F. 1976. Aannemingsorg en die beoefening daarvan, met behulp van die vakkundige dienste in die Nederduitsch Gereformeerde Kerk. Pretoria: University of Pretoria. (Unpublished DPhil Thesis)

LOURENS, J.A.E. 2002. Die toepassing van gesinsterapie met aangenome kinders. Pretoria: University of South Africa. (Unpublished MEd Dissertation)

MOUTON, G.E. 1976. Die aanneming van kinders, met besondere verwysing na die inpassing by die aannemende ouers. Bloemfontein: University of the Orange Free State. (Unpublished DSocSc (Social Work) Thesis)

NIJS, P. 1972. Donor inseminatie. (Sociaal) psychologische aspecten. Tijdschrift voor Geneeskunde, 28(23):1540-1546.

PAKATI, E.R.V. 1984. Legal adoption in an African community. Durban: University of Natal. (Unpublished MSocSc Dissertation)

SMITH, C. \& LOGAN, J. 2003. After adoption: direct contact and relationships. New York: Routledge.

VAN DELFT, W.F. 1983. Kunsmatige inseminasie met skenkersaad (KIS) as alternatief vir kinderlose egpare in Suid-Afrika. Pretoria: University of South Africa. (Unpublished DPhil Thesis)

WILSON, S. 2004. A current review of adoption research: exploring individual differences in adoption. Children and Youth Services Review, 26(8):687-696.

Prof Wilfred F van Delft, Department of Social Work, University of South Africa, Ms Trudie van Delft (adoption social worker, Die Ondersteuningsraad), Pretoria, South Africa. 